\title{
A Review of Pd Based Multimetallic Anode Electrocatalysts for Direct Formic Acid Fuel Cells
}

\author{
Berdan Ulas and Hilal Kivrak* \\ Van Yuzuncu Yil University, Department of Chemical Engineering, Van 65000, Turkey
}

Email: hilalkivrak@yyu.edu.tr (H. K.)

\begin{abstract}
Due to the increasing population and developing industry, the energy demand in the world is increasing. Fuel cells are technologies that can meet this need without a negative impact on the environment. However, for the commercialization of fuel cells, their costs must be reduced and their efficiency increased. An important way to reduce cost is to reduce the amount of $\mathrm{Pd}$, a precious metal used as an anode catalyst, by adding a second metal. The aim of this study is to explain how Pd increases the activity when used as an anode catalyst with a second metal for the formic acid electrooxidation.
\end{abstract}

Keywords palladium, formic acid, electrooxidation, alloy

\section{Introduction}

It is known that $28 \%$ of total greenhouse gas emissions are transport-related. ${ }^{[1]}$ Due to the increasing number of cars, this problem is expected to grow further in the coming years. Fossil fuels, which occupy a large part in today's automobile technology, have significant environmental impacts such as climate change and global warming. ${ }^{[2]}$ For these reasons, it is vital to investigate alternative energy sources. Renewable energy sources can be listed as sunlight, rain, waves, wind, tides, hydrogen, and geothermal energy, among which hydrogen energy provides effective solutions for environmental problems caused by fossil fuels. ${ }^{[3]}$

Fuel cells are eco-friendly energy conversion systems since they produce electrical energy utilizing hydrogen. Fuel cells can be classified as phosphoric acid, solid oxide, polymer exchange membrane, molten carbonate and alkali fuel cells based on the electrolyte type employed in the system. ${ }^{[4]}$ Among these, polymer exchange membrane fuel cell is the closest fuel cell type to commercialization. However, researchers have turned their research to look for safer direct liquid fuel cells (DLFCs) due to the cost and danger associated with the storage and transportation of hydrogen.

With their own advantages and drawbacks, the applications of various alcohols and non-alcohol fuels in different DLFC systems have been reported in the literature. The most commonly investigated DLFCs are direct methanol (DMFC), direct ethanol (DEFC), direct ethylene glycol (DEGFC), direct hydrazine (DHFC), direct dimethyl ether (DDMEFC), direct $\mathrm{NaBH}_{4}$ (DBFC), direct formate (DFFC), direct glucose (DGFC), and direct formic acid (DFAFC) fuel cells. Various studies related to these fuel cells are summarized in Table 1. Toxicity and membrane crossover problems of DMFCs, slow oxidation of ethanol at anode, formation of side products and need for high operating temperature in DEFCs and incomplete oxidation of ethylene glycol due to the release of unwanted by-products in DEGFCs are some of the obstacles encountered within these studies. ${ }^{[5]}$ Hence, further work is needed to improve the performance of abovementioned systems and there is still an increasing interest for other liquid fuel alternatives. ${ }^{[6]}$

The use of formic acid in fuel cells as a small organic molecule offers many advantages such as low operating
Table 1 Fuel cell types and their anode catalysts

\begin{tabular}{ccc}
\hline Fuel Cell Type & Anode Catalyst & Ref. \\
\hline DMFC & Pt@Ru/C & {$[10]$} \\
DEFC & Pt/C & {$[11]$} \\
DMFC & PtRu/C & {$[12]$} \\
DMFC & PtCo/SBA-15 & {$[13]$} \\
DEFC & PtIr@C & {$[14]$} \\
DEFC & PtRu/C & {$[15]$} \\
DEFC & $\mathrm{PtSn/CNT}$ & {$[16]$} \\
DEFC & PdAu/CNT & {$[17]$} \\
DEGFC & Pt/CNT & {$[18]$} \\
DEGFC & PdAuCo/CNT & {$[6]$} \\
DHFC & $P d$ & {$[19]$} \\
DDMEFC & PtRuPd/C & {$[20]$} \\
DGFC & Graphene//TO & {$[21]$} \\
DGFC & B doped graphene/ITO & {$[22]$} \\
DBFC & PtZn/C & {$[23]$} \\
DFAFC & PdZn/CNT & {$[24]$} \\
\hline
\end{tabular}

temperature, minimal crossover, high theoretical open circuit potential, high energy density, and low adverse effects on nature. ${ }^{[7,8]}$ Low toxicity, non-flammability, ready availability, and high electrooxidation rate strengthens the potential use of formic acid as an alternative fuel in DLFCs. ${ }^{[5]}$ Being a natural biomass and $\mathrm{a} \mathrm{CO}_{2}$ reduction product made formic acid an alternative in many DLFC studies. ${ }^{[9]}$

Anode catalysts for DLFCs are being investigated extensively. Table 1 represents the variation of anode catalyst types and their usage in different fuel cell systems. Since fuel cell performance tests of anode catalysts have not been performed in most of the studies in the literature, it is not possible to thoroughly compare the performance of fuel cells with each other.

The decomposition of formic acid on an anode catalyst follows either direct or indirect pathway. In the latter, dehydration of $\mathrm{HCOOH}$ to surface poisoner $\mathrm{CO}$ occurs. ${ }^{[25]}$ In other words, the dehydrogenation reaction (direct pathway) is the desired pathway for formic acid electrooxidation. ${ }^{[26]}$ Reactions of dehydrogenation and dehydration pathways are given in Eqs. (1) and (2), respectively.

$$
\mathrm{HCOOH} \rightarrow \mathrm{CO}_{2}+2 \mathrm{H}^{+}+2 \mathrm{e}^{-}
$$


$\mathrm{HCOOH} \rightarrow \mathrm{CO}+\mathrm{H}_{2} \mathrm{O} \rightarrow \mathrm{CO}_{2}+2 \mathrm{H}^{+}+2 \mathrm{e}^{-}$

Figure 1 shows a schematic representation for the working principle of a DFAFC. DFAFCs consist of an anode, cathode, and proton exchange membrane. Formic acid, which is used as fuel, is subjected to dehydrogenation reaction in the anode catalyst layer to form protons and electrons. While protons are transferred to the cathode side through the proton exchange membrane, electrons pass through the external circuit to generate electricity. On the cathode side, supplied $\mathrm{O}_{2}$, electrons coming from the outer circuit and protons passing through the membrane react, and water is released. The anode, cathode and overall reactions taking place in a DFAFC are shown in Eqs. (3), (4) and (5), respectively.

$$
\begin{aligned}
& \mathrm{HCOOH} \rightarrow \mathrm{CO}_{2}+2 \mathrm{H}^{+}+2 \mathrm{e}^{-} \\
& 1 / 2 \mathrm{O}_{2}+2 \mathrm{H}^{+}+2 \mathrm{e}^{-} \rightarrow \mathrm{H}_{2} \mathrm{O} \\
& \mathrm{HCOOH}+1 / 2 \mathrm{O}_{2} \rightarrow \mathrm{CO}_{2}+\mathrm{H}_{2} \mathrm{O}
\end{aligned}
$$

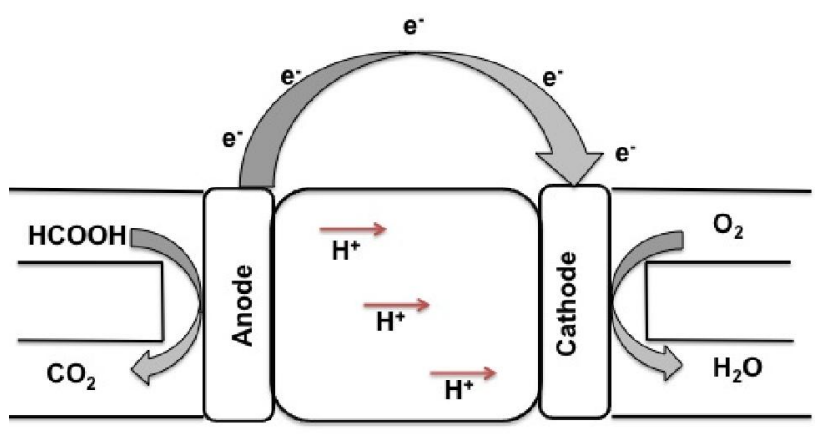

Proton Exchange Membrane

Figure 1 Schematic representation for working principle of DFAFC.

$\mathrm{Pt}$ and $\mathrm{Pd}$ are the two main electrocatalysts, on which electrooxidation of formic acid has been investigated since 1960's. ${ }^{[9]}$ In several studies, higher tendency of Pt and Pt-based catalysts to poisoning rather than $\mathrm{Pd}$-based catalysts was reported. Additionally, oxidation of formic acid to $\mathrm{CO}_{2}$ through dehydrogenation pathway takes place on Pd-based catalysts without any intermediate formation. ${ }^{[27,28]} \mathrm{Pd}$ and $\mathrm{Pt}$ have the same number of electrons at their outer shell and their physicochemical properties are quite parallel to each other. On the other hand, $\mathrm{Pd}$ is much more cost-effective, its abundance on earth is about fifty times higher than $\mathrm{Pt}^{[29]}$ and higher resistance of $\mathrm{Pd}$ to $\mathrm{CO}$ poisoning is reported in the literature. ${ }^{[30,31]}$ Additionally, Pd-based electrocatalysts show high activity in alkaline media for the oxidation of numerous substrates. ${ }^{[32]} \mathrm{Pd}$ shows a high initial activity during formic acid electrooxidation, while it loses this activity during long term performance. This result is mostly explained by the poisoning of $\mathrm{Pd}$ majorly by $\mathrm{CO}$ and some anions of the electrolyte. Additionally, high dissolution rate at acidic conditions weakens the durability and stability of the Pd based catalysts. ${ }^{[33]}$ Therefore, numerous studies searching for different strategies to improve the catalytic performance of $\mathrm{Pd}$ have been conducted. Alloying of $\mathrm{Pd}$ with different metals reduces the cost of the catalyst while maintaining its oxidizing activity. Enhanced performance of alloys is often explained by the coupling of ligand and ensemble effects. Ensemble effects are described as changes in the electronic state and catalytic properties of the surface, while ligand effects generally represent changes in the chemical properties of surface atoms. ${ }^{[34,35]}$

Palladium based nanoparticles have been synthesized by several techniques, namely electrodeposition, ${ }^{[36]}$ chemical reduction, ${ }^{[37]}$ ion exchange, ${ }^{[38]}$ solvothermal, ${ }^{[39]}$ sol-gel, ${ }^{[40]}$ colloidal, ${ }^{[41]}$ and polyol ${ }^{[42]}$ methods. To the best of our knowledge, colloidal methods have been reported most frequently in the literature. In order to synthesize Pd nanoparticle by colloidal method, a reducing agent and stabilizer are required. A reducing agent provides reduction of metal salt to $\mathrm{Pd}^{\circ}$, while stabilizer prevents agglomeration of the synthesized particles. ${ }^{[43,44]}$ In this method, Pd salt and reducing agent concentration significantly affect the shape and size of the nanoparticles ${ }^{[45]}$ Furthermore, the ratio of the amount of Pd salt to reducing agent is the main cause of by-products formed subsequent to synthesis. X-ray photoelectron spectroscopy (XPS) is the most commonly used technique for the detection of by-products.

\section{Structure Sensitivity}

Catalytic reactions can be classified according to many criteria. One of these classifications is made using the relation of turnover rate with particle size. Accordingly, alteration in turnover rate with the change in particle size is called structure sensitivity while catalysts that exhibit otherwise are classified as structure insensitivity. ${ }^{[46]}$

Metal catalysts are classified as structure sensitivity catalysts and are generally used in nanoscale. Because the reactions take place only on the surface and the catalysts in nanoscale have a wider surface than the larger particle size. ${ }^{[47]}$ Therefore, the efficiency of the nanoscale catalysts is higher than the others. ${ }^{[48,49]}$

It is very important to adjust the particle size, which directly affects the activity of the metal catalysts. The main factors affecting particle size are synthesis parameters, namely precursor type, synthesis temperature, reduction time of metal salt, and precursor concentration. ${ }^{[50]}$

The effect of $\mathrm{Pd}$ morphology at the nanoscale is an intensively investigated issue. Its significant effect on the electrocatalytic performance was emphasized by many authors. ${ }^{[51,52]}$ Zhang et al. have used one-pot synthesis method to produce $\mathrm{Pd}-\mathrm{Zn}$ nanocrystals ( $\mathrm{Pd}-\mathrm{Zn} \mathrm{NCs}$ ) by reducing transition metal ions in the existence of ascorbic acid and noble metals. High activity and stability for formic acid electrooxidation with the catalytic activity of $1945 \mathrm{~mA} / \mathrm{mg} \mathrm{Pd}$ were reported. High tolerance of the catalysts to $\mathrm{CO}$ poisoning was attributed to the synergistic effect between $\mathrm{Pd}$ and $\mathrm{Zn}$ in the structure of $\mathrm{Pd}-\mathrm{Zn} \mathrm{NCs} .^{\left[{ }^{[3]}\right.}$ In another study of the same research group, $\mathrm{PdCo}$ nanodots (PdCo Nds) were synthesized on graphene as an anode catalyst using in situ adsorption-reduction method. Oxidation peak current density for formic acid electrooxidation was reported to be 1362.1 $\mathrm{mA} / \mathrm{mg} \mathrm{Pd}$, which is the highest value among the PdCo based alloy catalysts. ${ }^{[54]}$

Huang et al. used galvanic displacement electrochemical reaction to prepare PdAg@Pd core-shell nanotubes with high electrocatalytic activity for formic acid electrooxidation. They compared the potential of PdAg@Pd core-shell nanotubes to that of $\mathrm{PdAg}$ nanotubes and reported the mass activity and specific activity values as $1930 \mathrm{~mA} / \mathrm{mg}_{\mathrm{Pd}}$ and $2.67 \mathrm{~mA} / \mathrm{cm}^{2}$. [55]

\section{Unsupported Pd Based Alloy Electrocatalysts}

Major disadvantages of $\mathrm{Pd}$ are reported to be the dissolution and corrosion problems encountered especially in acidic conditions. Formation of Pd-based alloys by the addition of a second metal is one of the frequently used strategy in order to modify the outer electronic structure of $P d$ and hence increase its catalytic activity. ${ }^{[28]}$ Performance of binary and ternary $\mathrm{Pd}$-based alloys such as $\mathrm{PdPt}, \mathrm{Pd}-\mathrm{Au}, \mathrm{Pd}-\mathrm{Ru}, \mathrm{Pd}-\mathrm{Pb}$, $\mathrm{PdCo}, \mathrm{PdNi}, \mathrm{PdCu}, \mathrm{Pdl}, \mathrm{PdRh}, \mathrm{PtBi}, \mathrm{PdAg}$ and $\mathrm{PdAuCu}$, AuPdPt, PdSnPt have been frequently studied in the literature 
Table 2 Recent studies on unsupported Pd based catalysts for formic acid electrooxidation

\begin{tabular}{|c|c|c|c|c|}
\hline Catalysts & Preparation Method & $\begin{array}{l}\text { Mass Activity/ } \\
\left(\mathrm{mA} / \mathrm{mg}_{\mathrm{Pd}}\right)\end{array}$ & Used Solution & Ref. \\
\hline $\mathrm{PdZn}$ & One-pot synthesis process in dimethylformamide & 1945 & $0.1 \mathrm{M} \mathrm{HClO}_{4}+0.5 \mathrm{M} \mathrm{HCOOH}$ & [97] \\
\hline $\mathrm{PdCu}$ & Staged thermal treatment route & 1108.2 & $0.5 \mathrm{M} \mathrm{H}_{2} \mathrm{SO}_{4}+0.5 \mathrm{M} \mathrm{HCOOH}$ & [67] \\
\hline $\mathrm{Pd}$ & One-pot synthesis with tannic acid & 304 & $0.5 \mathrm{M} \mathrm{H}_{2} \mathrm{SO}_{4}+0.5 \mathrm{M} \mathrm{HCOOH}$ & [68] \\
\hline PtPdCu & One-pot liquid phase chemical reduction & - & $0.5 \mathrm{M} \mathrm{H}_{2} \mathrm{SO}_{4}+1 \mathrm{M} \mathrm{HCOOH}$ & [69] \\
\hline PdRu & Polyol reduction method & 850 & $0.5 \mathrm{M} \mathrm{HClO}_{4}+0.5 \mathrm{M} \mathrm{HCOOH}$ & {$[70]$} \\
\hline $\mathrm{PdBi}$ & Wet-chemical method & 1628.5 & $0.5 \mathrm{M} \mathrm{H}_{2} \mathrm{SO}_{4}+0.5 \mathrm{M} \mathrm{HCOOH}$ & {$[71]$} \\
\hline $\mathrm{PdCu}$ & One-pot method with AA & 986.1 & $0.5 \mathrm{M} \mathrm{H}_{2} \mathrm{SO}_{4}+0.5 \mathrm{M} \mathrm{HCOOH}$ & {$[98]$} \\
\hline PtPd & Co-chemical reduction method & 960 & $0.5 \mathrm{M} \mathrm{H}_{2} \mathrm{SO}_{4}+0.5 \mathrm{M} \mathrm{HCOOH}$ & {$[74]$} \\
\hline PdPt & Electrodeposition & 1200 & $0.3 \mathrm{M} \mathrm{HCOOH}$ & [72] \\
\hline $\mathrm{PdAg}$ & Galvanic replacement & ca. 550 & $0.1 \mathrm{M} \mathrm{HClO}_{4}+0.1 \mathrm{M} \mathrm{HCOOH}$ & [99] \\
\hline $\mathrm{PdPt}$ & Polyol method & - & $0.5 \mathrm{M} \mathrm{H}_{2} \mathrm{SO}_{4}+0.5 \mathrm{M} \mathrm{HCOOH}$ & {$[75]$} \\
\hline $\mathrm{CuO}_{x}-\mathrm{Pd}$ & Electrodeposition & - & $0.3 \mathrm{M} \mathrm{HCOOH}$ & [73] \\
\hline
\end{tabular}

for formic acid electrooxidation. ${ }^{[56-61]}$ Table 2 summarizes recent studies on formic acid electrooxidation with unsupported Pd-based catalyst.

$\mathrm{Pd}$ loading can be reduced and electrocatalytic performance can be improved by the application of alloy catalysts. ${ }^{[62-65]}$ Behind the alloying strategy, three main effects namely ligand effect, geometric effect and ensemble effect are being discussed. ${ }^{[66]}$

Using staged thermal treatment route, Zhang et al. synthesized twisted $\mathrm{PdCu}$ nanochains that resulted with many catalytic active sites and modified electronic effects. Compared to previously reported $\mathrm{PdCu}$ alloy catalysts, a relatively high catalytic activity and stability with 1108.2 and $30.7 \mathrm{~mA} / \mathrm{mg} \mathrm{Pd}$ were obtained for formic acid electrooxidation. A possible effect of $\mathrm{Cu}$ precursors on the reduction rate of $\mathrm{Pd}$ species was discussed in the related study. The researchers suggested that the main reasons for the increase in electocatalytic properties were the twisted nanochain structure of the catalyst and its very small size. However, it is thought that the defects shown in TEM images have also contributed to the improved activity and stability. ${ }^{[67]}$ Wang et al. have employed tanning acid both as the reagent and the stabilizer at the same time and developed an eco-friendly synthesis method for the production of polycrystalline palladium nanoparticles. Developed catalyst has improved the efficiency and durability for formic acid electrooxidation thanks to its large electrochemical surface area and resulted in $304.00 \mathrm{~mA} / \mathrm{mg}_{\mathrm{Pd}}$ of mass activity value. This increased performance of the catalysts has been attributed to their increased poisoning tolerance. In particular, the effect of average particle sizes of $\mathrm{Pd}$ catalyst on activity and stability was emphasized. As in the study conducted by Zhang et al., formic acid electrooxidation activity was reported to decrease with increasing Pd size. With the smallest particle size $(12 \mathrm{~nm})$, this trend is disrupted due to the agglomeration of small $\mathrm{Pd}$ nanoparticles. Investigating this very important result of the study for multimetal catalysts would be very useful for the future of electrocatalysts. ${ }^{[68]}$ The study conducted by Zhang et al. focused on the metal ratios of the Pd-Zn alloy catalysts, and it was emphasized that the formic acid electrooxidation activity changed significantly with varying metal ratios. All synthesized $\mathrm{Pd}-\mathrm{Zn}$ alloy catalysts showed higher mass activity and durability in $4000 \mathrm{~s}$ than that of $\mathrm{Pd} / \mathrm{C}$. In addition, the stability of all $\mathrm{Zn}$ containing catalysts has increased compared to that of $P d / C$, indicating the ability of $\mathrm{Zn}$ to prevent $\mathrm{CO}$ poisoning. The researchers explained the increased activity to the nanostructure of the $\mathrm{Pd}-\mathrm{Zn}$ alloy and the synergistic effect between the metals. The researchers reported that $\mathrm{ZnO}$ accumulation occurs at a high zinc amount while the reaction proceeds on the dehydration pathway at low $\mathrm{Zn}$ amount. Therefore, they emphasize the importance of the optimum $\mathrm{Pd}$ : $\mathrm{Zn}$ ratio for the highest catalytic activity and durability. It has been proved that only the metal ratio optimization can increase the mass activity of $\mathrm{PdZn}$ catalysts by about 3 times. On the other hand, the chemical reasons for the positive contribution of molar ratios of metals to activity and stability have not been studied in detail. ${ }^{[53]} \mathrm{PdPtCu}$ truncated-octahedral morphology was investigated by $L v$ et al. They reported that trimetallic catalyst shows better performance than $\mathrm{Pt}$. Although the catalyst in the trimetallic octahedral structure is promising, researchers have not extensively reported the cause of improved activity and stability. Improved activity and stability were attributed to $\mathrm{Pd}$ and $\mathrm{Cu}$ that change the electronic structure of $\mathrm{Pt}$, but they did not report the details of this change. ${ }^{[69]}$ Kang et al. stressed that there is a volcano shape dependence between the size of the PdRu alloy and the activity of formic acid electrooxidation. The low activity values observed with small particle size have been explained by the formation of palladium hydride. Wang et al. ${ }^{[68]}$ reported similar results for the relationship between electrochemical activity and particle size of $\mathrm{Pd}$. They attributed the decrease in the electrochemical activity of $\mathrm{Pd}$ with particle size less than $12 \mathrm{~nm}$ to agglomeration, while Kang et al. subjected to the formation of palladium hydride. ${ }^{[70]}$ Although the CA results for the highest activity PtRu catalyst indicate that the catalyst was poisoned by 
$\mathrm{CO}$ and other undetectable structures, this catalyst still has higher stability than that of commercial $\mathrm{Pd} / \mathrm{C}^{[70]} \mathrm{Xu}$ et al. synthesized $\mathrm{PdBi}$ nanodots by controlling the size of the catalyst. The PdBi catalyst was prepared by the wet chemical method, and the particle size $(2.5 \mathrm{~nm})$ was controlled by changing the synthesis time. It has been clearly demonstrated that particle size affects the formic acid electrooxidation activity significantly. One of the important reason why $\mathrm{PdBi}$ catalyst exhibits a high mass activity such as $1628.5 \mathrm{~mA} / \mathrm{mg}_{\mathrm{Pd}}$ is the very homogeneous dispersion of the nanodots. The stability of $\mathrm{PdBi}$ nanodots has also been reported to be higher than $\mathrm{Pd} / \mathrm{C}$. This suggests that the effect of $\mathrm{Bi}$ addition on stability is greater than the catalyst size impact. ${ }^{[71]}$ PtPd core-shell catalysts were prepared by Al-Akraa et al. via electrodeposition method, and the core-shell structure is clearly shown with TEM images. In particular, the loading of $\mathrm{Pd}$ on $\mathrm{Pt}$ is optimized for maximum formic acid electrooxidation performance. Possible CO poisoning of $\mathrm{Pt}$ was prevented by the $\mathrm{Pd}$ shell, thereby improving stability and activity was observed. Formic acid electrooxidation proceeds predominantly by dehydrogenation on the Pd surface and by dehydration on the Pt surface. The authors emphasized this by using Pt in both the core and shell. In addition, maximum electrocatalytic activity was obtained with $6 \mathrm{Pd}$ monolayer. The unique aspect of this study is the optimization of the number of $\mathrm{Pd}$ layer on the $\mathrm{Pt}$ core for maximum electrocatalytic activity with the optimum $\mathrm{Pd}$ amount. ${ }^{[72]}$ The same research group also investigated the formic acid electrooxidation activity of $\mathrm{CuO}_{x}-\mathrm{Pd}$ prepared by the electrodeposition method. In this study, researchers used $\mathrm{CuO}_{x}$ instead of $\mathrm{Pt}$ and optimized $\mathrm{CuO}_{x}$ quantity was loaded on $\mathrm{Pd}$. According to their previous studies, $\mathrm{CuO}_{x}-\mathrm{Pd}$ exhibited much higher specific activity compared to that of core-shell PdPt $\left(6.5>2.54 \mathrm{~mA} / \mathrm{cm}^{-2}\right)$ despite the use of less precious metal content. ${ }^{[73]}$ The PdPt bimetallic catalyst was also investigated by other groups. For example, Qian et al. synthesized PtPd NPs with an average particle size of $6.5 \mathrm{~nm}$ using octa-maleamic acid silsesquioxanes (OM-POSS) as a stabilizing agent and optimized the metal precursor/OM-POSS ratio to achieve the highest dipersion value. The higher electrocatalytic activity of PdPt NPs compared to $\mathrm{Pt} / \mathrm{C}$ was attributed to the very good dispersion of PdPt NPs. This strategy was proposed so that the catalyst was not exposed to $\mathrm{CO}$ poisoning. The stability of PtPd $\mathrm{NPs}$ is 1.7 and 5.6 times higher than Pt NPs and Pt/C, respectively. The researchers explained this with OM-POSS presence, which prevents the agglomeration of nanoparticles. Furthermore, the isolation of $\mathrm{Pt}$ atoms using a second metal is the main reason for alloy catalysts with high activity and stability. Using this strategy, Qian et al. developed a promising catalyst system. ${ }^{[7]}$ Gralec et al. prepared PdPt nanocatalyst with polyol method with very low $\mathrm{Pt}$ ratio. According to the results of the characterization, $\mathrm{Pt}$ enters the $\mathrm{Pd}$ lattice structure, thereby changing the electronic properties of $\mathrm{Pd}$ and improved the formic acid electrooxidation performance. Although the researchers reported similar results to other PdPt catalyst results, they did not investigate the stability properties of the catalyst. ${ }^{[75]}$

\section{Supported Pd Based Alloy Electrocatalysts}

It is known that the formation of small crystals with high uniformity promotes active sites and catalytic activity due to its enhancement effect on accessible surface area, which in the end increases the utilization ratio of $\mathrm{Pd} .{ }^{[76]}$ Another strategy to improve the catalytic activity of Pd-based catalysts is to utilize surfactants, polymers and ligands. This strategy mostly results with decreased active areas because of the unwanted adsorption of organic species. ${ }^{[51]}$ In order to overcome this situation, support materials with high surface area and anchoring sites are being investigated. Carbon nanotubes (CNTs) with their high electrical conductivity and chemical stability are one of these support materials. ${ }^{[7]}$ Table 3 summarizes recent studies on formic acid electrooxidation with supported Pd-based catalysts.

The electrooxidation of $\mathrm{HCOOH}$ on $\mathrm{Pd}$ takes place by the following reaction:

$$
\begin{aligned}
& \mathrm{HCOOH}+\mathrm{Pd} \rightarrow \mathrm{HCOO}-\mathrm{Pd}+\mathrm{H}^{+}+\mathrm{e}^{-} \\
& \mathrm{HCOO}-\mathrm{Pd} \rightarrow \mathrm{Pd}-\mathrm{H}+\mathrm{CO}_{2}
\end{aligned}
$$

In this reaction, $\mathrm{HCOO}$ is adsorbed onto the Pd surface as an intermediate. The strength of the bond between $\mathrm{Pd}-\mathrm{O}$ is the primary determinant for the catalytic activity. This bond weakens as the difference between Pd's d-band center and Fermi level increases, whereas in the opposite case it becomes stronger. The d-band center position affecting the bond strength between HCOO-Pd should be optimized to obtained high electocatalytic activity. ${ }^{[78]}$ Recently, it has become more common to optimize the d-band center position by adding early transition metals onto the $\mathrm{Pd}$. The addition of a second early transition metal to the Pd catalyst causes the Pd-Pd bond to be compressed, thereby changing the electronic structure of the surface. $^{[79]}$

The studies carried out by our research group also benefited from the mentioned features of CNT. The most important motivation in our studies is to determine the optimum $\mathrm{d}$-band center value by modifying the $\mathrm{Pd}$ surface with other metals and thereby increasing the electrocatalytic activity of $\mathrm{Pd}$. Caglar et al. used $\mathrm{NaBH}_{4}$ reduction method to synthesize CNT supported Pd catalysts. Several synthesis parameters were optimized by using Central Composite Design in order to obtain maximum mass activity toward formic acid electrooxidation. Reported values were $974.80 \mathrm{~mA} / \mathrm{mg}_{\mathrm{Pd}}$ theoretically and $920 \mathrm{~mA} / \mathrm{mg}_{\mathrm{Pd}}$ experimentally. Optimized parameters were applied in formic acid fuel cell measurements and better results were obtained for Pd/CNT compared to commercial Pd black catalysts. ${ }^{[18]}$ In the study of Ulas et al., the molar ratio of Pd and $\mathrm{Ni}$ was optimized to maximize the potential of CNT supported $\mathrm{PdNi}$ alloy catalysts towards formic acid electrooxidation for the first time in the related literature. $\mathrm{NaBH}_{4}$ reduction was the method of choice to produce catalysts with at desired molar composition. The reported maximum mass acitivity value was $613.9 \mathrm{~mA} / \mathrm{mg}_{\mathrm{Pd}}$ for $\mathrm{PdNi} / \mathrm{CNT}$ with $90: 10$ molar ratio. PdNi/CNT with $90: 10$ molar ratio exhibited the highest stability at the end of $1000 \mathrm{~s}$, while all $\mathrm{Ni}$ containing catalysts showed higher stability than that of $\mathrm{Pd} / \mathrm{C}$. As previously reported many times, the increased activity and stability with the presence of $\mathrm{Ni}$ have been attributed to the synergy between $\mathrm{Pd}$ and $\mathrm{Ni}$. In addition, the change in the electronic properties of $\mathrm{Pd}$ with the addition of $\mathrm{Ni}$ is the main component of this synergy. ${ }^{[00]}$ Ulas et al. investigated the effect of molar atomic ratio on the potential of carbon supported Pd based binary and ternary alloy catalysts, which are synthesized by using $\mathrm{NaBH}_{4}$ reduction method. They reported maximum mass activity as $428.3 \mathrm{~mA} / \mathrm{mg}$ Pd for ternary alloy catalyst PdAgNi $(70: 20: 10)$. It was also observed that the catalytic activity decreased with the addition of $\mathrm{Ni}$ to the $\mathrm{PdAg} / \mathrm{CNT}$ catalyst, while the stability of the catalyst increased. The synergistic effect and electronic promotion effect, as well as the optimization of the molar composition, were emphasized in the related study as an explanation of the enhanced performance compared to that of $\mathrm{Pd} / \mathrm{C}$. The PdAgNi catalyst showed lower electrochemical activity than that of PdNi/CNT. The main reason for this is thought to be the agglomeration of the $\mathrm{PdAgNi} / \mathrm{CNT}$ nanoparticles and partial reduction of the Nickel salt. ${ }^{[81]} \mathrm{Xu}$ et al. optimized the atomic ratio between $\mathrm{Pd}$ 
Table 3 Recent studies on supported Pd based catalysts for formic acid electrooxidation

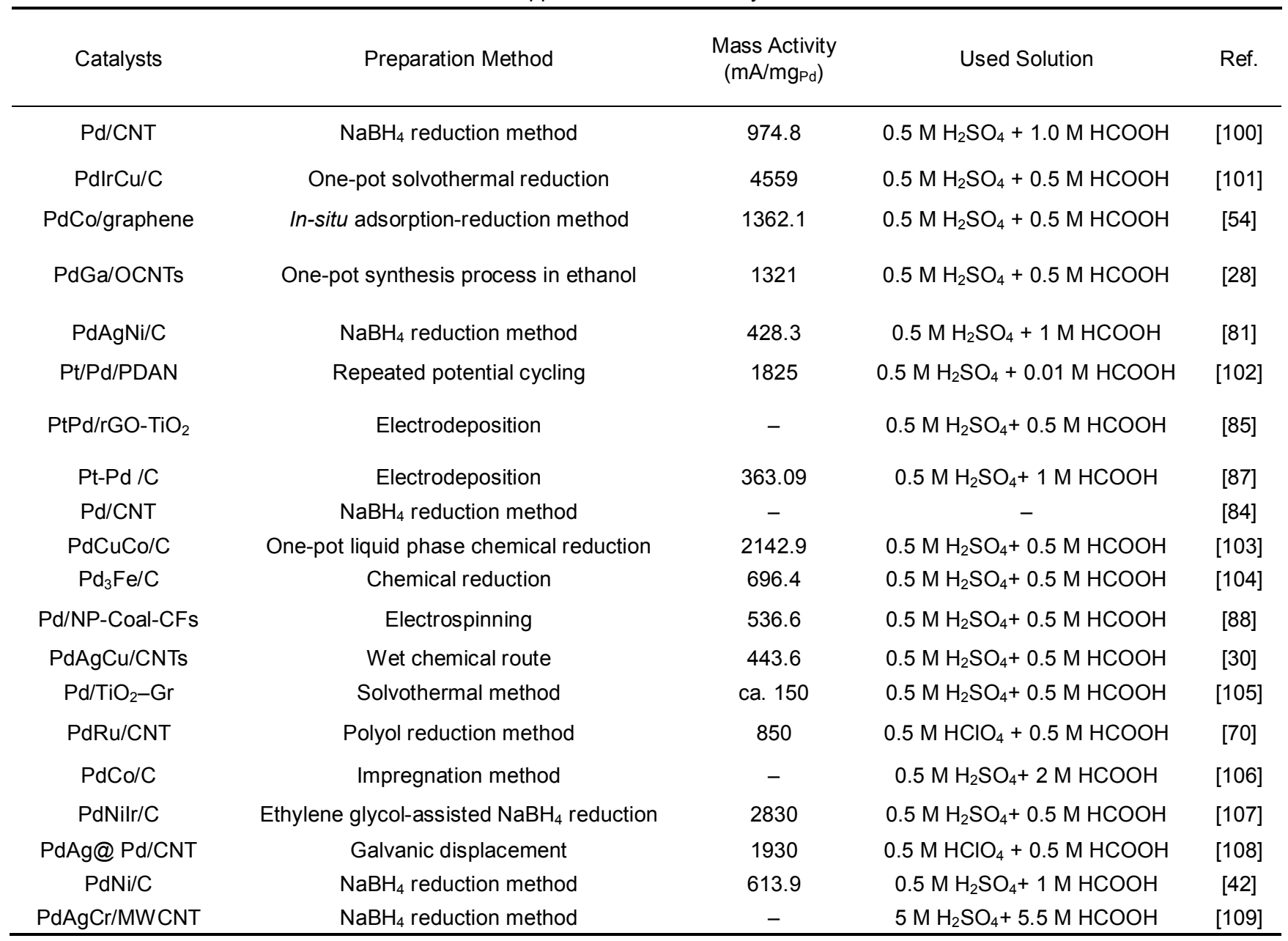

and $\mathrm{Ga}$ on functionalized carbon nanotubes for formic acid electrooxidation. The highest mass activity $\left(1321 \mathrm{~mA} / \mathrm{mg}_{\mathrm{Pd}}\right)$ and the long term stability were reported for PdGa $(3.9: 1)$. The researchers attributed this result to the positive contribution of funcitonalized CNT and to the weakening of the adsorption of format intermediate on the $\mathrm{Ga}$ modified $\mathrm{Pd}$ surface. ${ }^{[28]}$ In addition, the carbon supported Pd catalyst was modified with $\mathrm{Au}, \mathrm{V}, \mathrm{Co}, \mathrm{Mn}, \mathrm{Zn}$ in other studies carried out by our research group. All $\mathrm{PdAu} / \mathrm{C}$ catalysts at different metal ratio showed higher electrocatalytic activity than $\mathrm{Pd} / \mathrm{C}$. It was observed from $\mathrm{CO}$ stripping voltammograms of $\mathrm{PdAu} / \mathrm{C}$ that the stability and poisoning tolerance of the catalyst increased with the addition

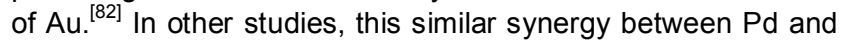
Au has been observed between Pd and Co. Despite the sudden drop in initial current, $\mathrm{PdCo} / \mathrm{C}$ has the highest current density at the end of $1000 \mathrm{~s}$. This improvement in stability is due to the introduction of $\mathrm{Co}$ atoms into the lattice structure of $\mathrm{Pd}$, thereby changing its surface properties. ${ }^{[83]}$

Mazurkiewicz-Pawlicka et al. used the ammonia solution to increase the catalytic activity of Pd deposited on CNTs. Ammonia solution was used for the removal of polynuclear aromatic compounds, which are formed subsequent to the oxidation of multiwall CNTs and likely to be adsorbed on the metal active sites. The maximum specific power density reported in the related study was $216 \mathrm{~mW} / \mathrm{mg} \mathrm{Pd}{ }^{[84]}$ Promsawan et al. utilized titanium dioxide $\left(\mathrm{TiO}_{2}\right)$ modified reduced graphene oxide as the support material for the electro- deposition of $\mathrm{Pt}$ and $\mathrm{PtPd}$ catalysts. The improved electrocatalytic activity was referred to $\mathrm{Pd}$ and $\mathrm{TiO}_{2}$, as well as high electrochemically active surface area. Researchers have explained the high stability and low $\mathrm{CO}$ poisoning of the $\mathrm{PtPd} / \mathrm{rGO}-\mathrm{TiO}_{2}$ catalyst by the charge transfer between $\mathrm{rGO}$ and $\mathrm{TiO}_{2}$. In addition, the blocking of the interaction between $\mathrm{CO}$ and $\mathrm{Pt}$ by $\mathrm{Pd}$ atoms was observed in $\mathrm{CO}$ stripping tests. The improvement in the stability of the catalyst has been attributed to this behavior of $\mathrm{Pd}^{[85]}$ In the study of $\mathrm{Li}$ et al., PdAgCu NPs were constructed on MWCNTs support using a wet chemical route and its electrocatalytic activity through formic acid electrooxidation was studied. Catalytic performance was reported with mass activity value as $443.64 \mathrm{~mA} / \mathrm{mg} \mathrm{Pd}$. The contribution of $\mathrm{Cu}$ on the increased electrocatalytic activity was explained by the induced geometric effect and improved electronic interaction between $\mathrm{Pd}, \mathrm{Ag}$, and $\mathrm{Cu}$. Furthermore, researchers reported that changing the d-band center of $\mathrm{Pd}$ using an appropriate amount of $\mathrm{Ag}$ and further defect formation by $\mathrm{Cu}$ leaching are also among the main reasons for the good stability and improved activity values of the PdAgCu/MWCNT. However, this catalyst has lower electrocatalytic activity than other anode catalysts in the literature. The researchers have not reported the reason for this, but it can be said according to $\mathrm{CV}$ curves that the electrochemical activity of PdAgCu/MWCNT may have decreased due to $\mathrm{CO}$ poisoning. ${ }^{[30]}$

A significant increase in mass activity value for formic acid electrooxidation was obtained in the study of An et.al. Potential 
of ternary metal elements alloy has been investigated through the synthesis of a three dimensional Ir-alloyed ultrathin ternary PdlrCu nanosheets-composed flower structure (PdlrCu/C NCF) by one-pot solvothermal reduction method. Enhancement in the electrocatalytic properties obtained through $\mathrm{Ir}$ and $\mathrm{Cu}$ addition was explained by the prevention of $\mathrm{CO}$ poisoning, increasing the active sites by modifying the electronic structure of $\mathrm{Pd}$ and by facilitating charge transfer rate and mass transport. Utilization of Ir in this study was due to its high redox potential that provides high stability in acidic media as well as its ability to produce hydroxyl groups at low potentials, which prevents $\mathrm{CO}$ poisoning. Moreover, the stability of $\mathrm{PtIrCu} / \mathrm{C} \mathrm{NCF}$ catalyst is 9.56 times higher than $\mathrm{Pd} / \mathrm{C}$ due to its superior CO tolerance. ${ }^{[86]}$ Muthukumar et al. used electrodeposition technique and by changing the lower potential limit they produced Pt-Pd bimetallic catalysts with leaf-like and flower-like dendritic structures on carbon black coated carbon paper. The maximum power density values of the prepared catalysts were 49 $\mathrm{mW} / \mathrm{cm}^{2}$ and $20 \mathrm{~mW} / \mathrm{cm}^{2}$, respectively. The relatively low mass activity $\left(363.1 \mathrm{~mA} / \mathrm{mg}_{\mathrm{Pd}}\right)$ reported in this study may be caused by poisoning of the PtPd catalyst. In this study, the peak pointing to the total electrooxidation on the clean electrode surface in the reverse scan is approximately 3 times the peak indicating $\mathrm{HCOOH}$ dehydrogenation in the forward scan. It is emphasized from the researchers that nano leaf like PtPd possesses the highest long term stability (181.78 for $3600 \mathrm{~s}$ ) due to the high surface concentration of $\mathrm{Pt} .{ }^{[87]} \mathrm{A}$ similar situation was reported a study conducted by Lou et al. ${ }^{[88]}$ In this study, a shoulder peak of about $0.4 \mathrm{~V}$ was detected and in our opinion, this peak was caused by carbonaceous compounds.

Taking the advantage of their high surface area and porous structure, conducting polymers were also utilized as the support materials of catalysts. It is known that conducting polymers facilitate the flow of electronic charges and improves the efficiency of formic acid electrooxidation. ${ }^{[89]}$

\section{Pd Based Thin Film Electrocatalysts}

Synthesis of thin films is a novel method for preparing metal coatings, in which the surface of less precious metal is replaced with a noble metal through different techniques like immersion, sputtering, electrodeposition, etc. ${ }^{[90]}$ Thin film method minimizes the total amount of metal required while enabling the control of metal nanostructure, cluster size and dispersion. Type of the deposition technique and the related experimental parameters, as well as the surface properties of the substrate materials, are the other factors affecting the electrochemical characteristics and morphology of the synthesized thin film catalysts. ${ }^{\text {[91,92] }}$

In the very detailed study of Baldauf and Kolb, the effect of substrate material and film thickness on oxidation of formic acid was investigated. Based on these parameters, significant changes were observed in the catalytic properties of Pd. They used the electrodeposition technique to produce ultrathin $\mathrm{Pd}$ overlayers. The highest catalytic activity and resistance to $\mathrm{CO}$ poisoning were obtained for Pd overlayers with (100) orientation. Different atomic spacings of different substrates, namely $\mathrm{Au}, \mathrm{Pt}$, and native $\mathrm{Pd}$, have caused the differences in the electronic properties of the surfaces. ${ }^{[93]}$ Obradovic and Gojkovic has also used electrodeposition technique to prepare $\mathrm{Pd}$ thin films on polycrystalline Au substrates and investigated their potential for formic acid electrooxidation. Obtained electronic modification has resulted in high oxidation rate as well as rapid poisoning by $\mathrm{CO}^{\left[{ }^{[94]}\right.}$ Unlike to the study of Baldauf and Kolb, no XPS result was given in this study. Hu et al. used vapor deposition technique to prepare layered $\mathrm{Pd}-\mathrm{Cu}$ bimetallic thin films surfaces on glassy carbon. They have eliminated the obstacles encountered during electronic and electrochemical analyses of bimetallic nanoparticles. As the Pd film thickness decreases, D-band center is positioned away from the Fermi level and a positive binding energy shift arising from the charge transfer from $\mathrm{Pd}$ to $\mathrm{Cu}$ has observed. These changes indicates a significant modicification in surface electronic structure that resulted with higher peak current density, lower onset potential, and enhanced stability for formic acid electrooxidation. ${ }^{[95]}$ In the study of Kibler et al., Pd monolayers were prepared on different substrates namely, Au (111), Pt (111), PtRu (111), Rh (111), Ir (111), $\mathrm{Ru}(0001), \operatorname{Re}(0001)$ and $\mathrm{Pd}(111)$. It is reported in the study that shifting of the d-band center down resulted with an increase in the catalytic activity of palladium monolayer. ${ }^{[96]}$

\section{Conclusions and Perspectives}

The Pd-based catalysts have been extensively studied in the literature. However, the effect of Pd molar ratio and second metal on formic acid electrocatalytic activity was not investigated in many of these studies. In other words, the optimum d-band center has not been determined in many studies as a result of $\mathrm{Pd}$ surface modification with another metal. Thus, the maximum mass activity of the electrocatalysts used for formic acid electrooxidation cannot be achieved. In the future studies, the relationship between $d$-band center value and the electro- catalytic activity of the catalyst should be emphasized.

The electrooxidation of formic acid on Pd is predominantly carried out direct pathway. However, the large particle size of $\mathrm{Pd}$-based catalysts may result in lower activity than these of Pt-based catalysts. In our opinions, comprehensive studies on the synthesis methods of Pd-based catalysts are required. In most studies, electrochemical activity was increased by alloying $\mathrm{Pd}$ with a second metal and this increase was generally attributed to the possible bifunctional effect, electronic effect, synergistic effect and ligand effect. However, systematic studies examining these effects are very limited. We believe that electrocatalysts with higher activity and stability can be designed by illuminating these effects.

\section{Author Contributions}

The manuscript was written through contributions of all authors. All authors have given approval to the final version of the manuscript.

\section{References}

[1] Ahmadi, P.; Torabi, S. H.; Afsaneh, H.; Sadegheih, Y.; Ganjehsarabi, H.; Ashjaee, M. Int. J. Hydrog. Energy 2019, DOI: 10.1016/j.ijhydene.2019.01.165.

[2] Bulut, A.; Yurderi, M.; Alal, O.; Kivrak, H.; Kaya, M.; Zahmakiran, M. Adv. Powder Technol. 2018, 29, 1409.

[3] Sahin, A. Electrochim. Acta 2018, 271, 127.

[4] Demir Kivrak, H. Yakıt Pili Katalizörleri. Turkey, Gece Akademi, 2019.

[5] Ong, B. C.; Kamarudin, S. K.; Basri, S. Int. J. Hydrog. Energy 2017, 42, 10142

[6] Ulas, B.; Caglar, A.; Kivrak, V.; Kivrak, H. Chem. Pap. 2019, 73, 425.

[7] Bianchini, C.; Shen, P. K. Chem. Rev. 2009, 109, 4183.

[8] Zhu, Y.; Ha, S. Y.; Masel, R. I. J. Power Sources 2004, 130, 8.

[9] Jiang, K.; Zhang, H.-X.; Zou, S.; Cai, W.-B. Phys. Chem. Chem. Phys. 2014, 16, 20360.

[10] Kıvrak, H. D. B. Ulaş. Yüzüncü Yıl Üniversitesi Fen Bilimleri Enstitüsü Dergisi. 2017, 22, 21.

[11] Kivrak, H.; Kuliyev, S.; Tempel, H.; Schneider, J.; Uner, D. Int. J. Chem. React. Eng. 2011, 9, A36.

[12] Sahin, O.; Kivrak, H. Int. J. Hydrog. Energy 2013, 38, 901.

[13] Kivrak, H.; Can, M.; Duru, H.; Sahin, O. Int. J. Chem. React. Eng. 
2014, 12, 369

[14] Sahin, O.; Kivrak, H.; Karaman, M.; Atbas, D. Am. J. Mater. Sci. Eng. 2015, 3, 15.

[15] Sahin, O.; Duzenli, D.; Kivrak, H. Energy Sources Part A-Recovery Util. Environ. Eff. 2016, 38, 628.

[16] Atbas, D.; Caglar, A.; Kivrak, H.; Kivrak, A. Am. J. Nanomater. 2016, 4, 8.

[17] Caglar, A.; Kivrak, H. Int. J. Hydrog. Energy 2019, 44, 11734.

[18] Çağlar, A.; Aldemir, A.; Kivrak, H. Fuller. Nanotub. Carbon Nanostruct. 2018, 26, 863.

[19] Yamada, K.; Yasuda, K.; Tanaka, H.; Miyazaki, Y.; Kobayashi, T. J. Power Sources 2003, 122, 132.

[20] Li, Q.; Wen, X.; Wu, G.; Chung, H. T.; Gao, R.; Zelenay, P. Angew. Chem. Int. Ed. 2015, 54, 7524.

[21] Caglar, A.; Ulas, B.; Sahin, O.; Demir Kivrak, H. Energy Storage e73.

[22] Caglar, A.; Ulas, B.; Sahin, O.; Kıvrak, H. Int. J. Energy Res. 2019, 43, 8204.

[23] Yi, L.; Wei, W.; Zhao, C.; Yang, C.; Tian, L.; Liu, J.; Wang, X. Electrochimi. Acta 2015, 158, 209

[24] Yilmaz, Y.; Er, Ö. F.; Ulaş, B.; Kıvrak, H. D. Yüzüncü YıI Üniversitesi Fen Bilimleri Enstitüsü Dergisi. 2019, 24, 125.

[25] Kivrak, H.; Atbas, D.; Alal, O.; Çögenli, M. S.; Bayrakceken, A.; Mert, S. O.; Sahin, O. Int. J. Hydrog. Energy 2018, 43, 21886

[26] Flaherty, D. W.; Berglund, S. P.; Mullins, C. B. J. Catal. 2010, 269, 33.

[27] Yang, M.; Zhu, X.; Tang, Y.; Wu, P.; Lu, T. lonics 2015, 21, 2609

[28] Xu, S.; Zhang, J.; Wang, J.; Lv, L.; Sun, Y.; Huang, X.; Lin, T.-W.; Huang, X.; Shao, L.-D. Catal. Sci. Technol. 2019, 9, 1255.

[29] Antolini, E. Energy Environ. Sci. 2009, 2, 915

[30] Li, R.; Yuan, H.; Ma, Z.; Tang, B.; Li, J.; Wang, X. Electrochim. Acta 2019, 293, 149.

[31] Feng, L.; Chang, J.; Jiang, K.; Xue, H.; Liu, C.; Cai, W.-B.; Xing, W.; Zhang, J. Nano Energy 2016, 30, 355

[32] Bianchini, C.; Shen, P. K. Chem. Rev. 2009, 109, 4183.

[33] Ren, M.; Kang, Y.; He, W.; Zou, Z.; Xue, X.; Akins, D. L.; Yang, H.; Feng, S. Appl. Catal. B-Environ. 2011, 104, 49.

[34] Liu, P.; Nørskov, J. K. Phys. Chem. Chem. Phys. 2001, 3, 3814

[35] Meng, H.; Zeng, D.; Xie, F. Catalysts 2015, 5, 1221.

[36] Avci, C.; Cicek, F.; Kazici, H. C.; Kivrak, A.; Kivrak, H. Int. J. Nano Dimens. 2018, 9, 15.

[37] Karatas, Y.; Bulut, A.; Yurderi, M.; Ertas, I. E.; Alal, O.; Gulcan, M.; Celebi, M.; Kivrak, H.; Kaya, M.; Zahmakiran, M. Appl. Catal. B-Environ. 2016, 180, 586.

[38] Bavykin, D. V.; Lapkin, A. A.; Plucinski, P. K.; Torrente-Murciano, L.; Friedrich, J. M.; Walsh, F. C. Top. Catal. 2006, 39, 151.

[39] Zhen, F.; Ran, M.; Chu, W.; Jiang, C.; Sun, W. Chem. Phys. Lett. 2018, 695, 183.

[40] Sierra-Salazar, A. F.; Ayral, A.; Chave, T.; Hulea, V.; Nikitenko, S. I.; Abate, S.; Perathoner, S.; Lacroix-Desmazes, P. Unconventional Pathways for Designing Silica-Supported Pt and Pd Catalysts with Hierarchical Porosity. In Studies in Surface Science and Catalysis. 2019, Elsevier, p. 377-397.

[41] Mun, Y.; Lee, S.; Cho, A.; Kim, S.; Han, J. W.; Lee, J. Appl. Catal. B-Environ. 2019, 246, 82.

[42] Kazıcı, H. Ç.; Yayla, M.; Ulaş, B.; Aktaş, N.; Kivrak, H. Electroanalysis. 2019, 31, 1118.

[43] Reed, K. J. 2019, Google Patents.

[44] Ye, Z.; Li, C.; Skillen, N.; Xu, Y.; McCabe, H.; Kelly, J.; Robertson, P.; Bell, S. E. Appl. Mater. Today 2019, 15, 398.

[45] Rastogi, A.; Zivcak, M.; Sytar, O.; Kalaji, H. M.; He, X.; Mbarki, S.; Brestic, M. Front. Chem. 2017, 5, 78.

[46] Carberry, J. J. J. Catal. 1988, 114, 277.

[47] Arai, M. J. Chem. Eng. Jpn. 1997, 30, 1123.

[48] Kivrak, H.; Mastalir, Á.; Király, Z.; Uner, D. Catal. Commun. 2009, 10, 1002.

[49] Király, Z.; Mastalir, Á.; Császár, Á.; Demir, H.; Uner, D.; Findenegg,
G. H. J. Catal. 2007, 245, 267

[50] Duan, H.; Wang, D.; Li, Y. Chem. Soc. Rev. 2015, 44, 5778.

[51] Mazumder, V.; Sun, S. J. Am. Chem. Soc. 2009, 131, 4588.

[52] Huang, X.; Tang, S.; Mu, X.; Dai, Y.; Chen, G.; Zhou, Z.; Ruan, F.; Yang, Z.; Zheng, N. Nat. Nanotechnol. 2011, 6, 28.

[53] Zhang, X.; Fan, H.; Zheng, J.; Duan, S.; Huang, Y.; Cui, Y.; Wang, R. Catal. Sci. Technol. 2018, 8, 4757.

[54] Zhang, L. Y.; Gong, Y.; Wu, D.; Li, Z.; Li, Q.; Zheng, L.; Chen, W. Appl. Surf. Sci. 2019, 469, 305.

[55] Huang, L.; Yang, J.; Wu, M.; Shi, Z.; Lin, Z.; Kang, X.; Chen, S. J. Power Sources 2018, 398, 201.

[56] Cho, Y.-H.; Choi, B.; Cho, Y.-H.; Park, H.-S.; Sung, Y.-E. Electrochem. Commun. 2007, 9, 378.

[57] Xu, H.; Yan, B.; Zhang, K.; Wang, J.; Li, S.; Wang, C.; Shiraishi, Y.; Du, Y.; Yang, P. Electrochim. Acta 2017, 245, 227.

[58] Wang, M.; Ma, Z.; Li, R.; Tang, B.; Bao, X.-Q.; Zhang, Z.; Wang, X. Electrochim. Acta 2017, 227, 330.

[59] Sneed, B. T.; Brodsky, C. N.; Kuo, C.-H.; Lamontagne, L. K.; Jiang Y.; Wang, Y.; Tao, F. F.; Huang, W.; Tsung, C.-K. J. Am. Chem. Soc 2013, 135, 14691

[60] Kang, S.; Lee, J.; Lee, J. K.; Chung, S. Y.; Tak, Y. J. Phys. Chem. B 2006, 110, 7270

[61] Choi, J.-H.; Jeong, K.-J.; Dong, Y.; Han, J.; Lim, T.-H.; Lee, J.-S.; Sung, Y.-E. J. Power Sources 2006, 163, 71

[62] Du, C.; Chen, M.; Wang, W.; Yin, G. ACS Appl. Mater. Interfaces 2010, 3, 105

[63] Hu, S.; Scudiero, L.; Ha, S. Electrochem. Commun. 2014, 38, 107.

[64] Chang, J.; Feng, L.; Liu, C.; Xing, W.; Hu, X. Angew. Chem. Int. Ed. 2014, 53, 122.

[65] Demirci, U. B. J. Power Sources 2007, 173, 11.

[66] Strasser, P.; Koh, S.; Anniyev, T.; Greeley, J.; More, K.; Yu, C.; Liu Z.; Kaya, S.; Nordlund, D.; Ogasawara, H.; Toney, M. F.; Nilsson, A. Nat. Chem. 2010, 2, 454

[67] Zhang, L. Y.; Gong, Y.; Wu, D.; Wu, G.; Xu, B.; Bi, L.; Yuan, W.; Cui, Z. J. Colloid Interface Sci. 2019, 537, 366.

[68] Wang, H.-H.; Zhang, J.-F.; Chen, Z.-L.; Zhang, M.-M.; Han, X.-P.; Zhong, C.; Deng, Y.-D.; Hu, W.-B. Rare Metals 2019, 38, 115.

[69] Lv, P.; Li, L.; Yang, X.; Zhang, Y.; Yu, X.; Zhao, J. Catal. Lett. 2018, 148,3779

[70] Kang, X.; Miao, K.; Guo, Z.; Zou, J.; Shi, Z.; Lin, Z.; Huang, J.; Chen, S. J. Catal. 2018, 364, 183

[71] Xu, H.; Zhang, K.; Yan, B.; Wang, J.; Wang, C.; Li, S.; Gu, Z.; Du, Y.; Yang, P. J. Power Sources 2017, 356, 27.

[72] Al-Akraa, I. M.; Mohammad, A. M.; El-Deab, M. S.; El-Anadouli, B. E. Int. J. Hydrog. Energy 2015, 40, 1789.

[73] Al-Akraa, I. M.; Mohammad, A. M.; El-Deab, M. S.; El-Anadouli, B. E. J. Nanotechnol. 2018, 2018, 9.

[74] Qian, K.; Hao, F.; Wei, S.; Wang, Y.; Ge, C.; Chen, P.; Zhang, Y. J. Solid State Electrochem. 2017, 21, 297.

[75] Gralec, B.; Lewera, A. Appl. Catal. B-Environ. 2016, 192, 304

[76] Chen, X.; Wu, G.; Chen, J.; Chen, X.; Xie, Z.; Wang, X. J. Am. Chem. Soc. 2011, 133, 3693

[77] Shao, L.; Zhang, B.; Zhang, W.; Hong, S. Y.; Schlögl, R.; Su, D. S. Angew. Chem. Int. Ed. 2013, 52, 2114

[78] Gunji, T.; Matsumoto, F. Inorganics 2019, 7, 36.

[79] Xiao, W.; Liutheviciene Cordeiro, M. A.; Gong, M.; Han, L.; Wang, J.; Bian, C.; Zhu, J.; Xin, H. L.; Wang, D. J. Mater. Chem. A 2017, 5, 9867.

[80] Ulas, B.; Caglar, A.; Kivrak, H. Int. J. Energy Res. 2019, 43, 3436.

[81] Ulas, B.; Caglar, A.; Sahin, O.; Kivrak, H. J. Colloid Interface Sci. 2018, 532, 47

[82] Ulas, B.; Kivrak, A.; Aktas, N.; Kivrak, H. Fuller. Nanotub. Carbon Nanostruct. 2019, 27, 545

[83] Caglar, A.; Ulas, B.; Cogenli, M. S.; Yurtcan, A. B.; Kivrak, H. J. Electroanal. Chem. 2019, 850, 113402

[84] Mazurkiewicz-Pawlicka, M.; Malolepszy, A.; Mikolajczuk-Zychora, A.; Mierzwa, B.; Borodzinski, A.; Stobinski, L. Appl. Surf. Sci. 2019 
476, 806 .

[85] Promsawan, N.; Uppamahai, S.; Themsirimongkon, S.; Inceesungvorn, B.; Waenkaew, P.; Ounnunkad, K.; Saipanya, S. J. Nanopart. Res. 2018, 20, 258.

[86] An, H. M.; Zhao, Z. L.; Zhang, L. Y.; Chen, Y.; Chang, Y. Y.; Li, C. M. ACS Appl. Mater. Interfaces 2018, 10, 41293.

[87] Muthukumar, V.; Chetty, R. lonics 2018, 24, 3937.

[88] Lou, M.; Wang, R.; Zhang, J.; Tang, X.; Wang, L.; Guo, Y.; Jia, D.; Shi, H.; Yang, L.; Wang, X. ACS Appl. Mater. Interfaces 2019, 11, 6431.

[89] Ren, F.; Zhou, R.; Jiang, F.; Zhou, W.; Du, Y.; Xu, J.; Wang, C. Fuel Cells 2012, 12, 116.

[90] Lović, J.; Stevanović, S.; Tripković, D.; Jovanović, V.; Stevanović, R.; Tripković, A. V.; Popović, K. D. J. Electroanal. Chem. 2014, 735, 1.

[91] Paoletti, C.; Cemmi, A.; Giorgi, L.; Giorgi, R.; Pilloni, L.; Serra, E.; Pasquali, M. J. Power Sources 2008, 183, 84

[92] Sarto, F.; Castagna, E.; De Francesco, M.; Dikonimos, T.; Giorgi, L.; Lecci, S.; Sansovini, M.; Violante, V. Int. J. Hydrog. Energy 2014, 39, 14701.

[93] Baldauf, M.; Kolb, D. J. Phys. Chem. 1996, 100, 11375.

[94] Obradović, M. D.; Gojković, S. L. Electrochim. Acta 2013, 88, 384.

[95] Hu, S.; Scudiero, L.; Ha, S. Electrochim. Acta 2012, 83, 354.

[96] Kibler, L. A.; El-Aziz, A. M.; Hoyer, R.; Kolb, D. M. Angew. Chem. Int. Ed. 2005, 44, 2080.

[97] Zhang, X.; Fan, H.; Zheng, J.; Duan, S.; Huang, Y.; Cui, Y.; Wang, R. Catal. Sci. Technol. 2018, 8, 4757.

[98] Yan, B.; Wang, C.; Xu, H.; Zhang, K.; Li, S.; Du, Y. ChemPlusChem
2017, 82, 1121.

[99] Liu, D.; Xie, M.; Wang, C.; Liao, L.; Qiu, L.; Ma, J.; Huang, H.; Long, R.; Jiang, J.; Xiong, Y. Nano Res. 2016, 9, 1590.

[100] Caglar, A.; Sahan, T.; Cogenli, M. S.; Yurtcan, A. B.; Aktas, N.; Kivrak, H. Int. J. Hydrog. Energy 2018, 43, 11002.

[101] An, H. M.; Zhao, Z. L.; Zhang, L. Y.; Chen, Y.; Chang, Y. Y.; Li, C. M. ACS Appl. Mater. Interfaces 2018, 10, 41293.

[102] Shatla, A.; Hassan, K.; Abd-El-Latif, A.; Hathoot, A.; Baltruschat, H.; Abdel-Azzem, M. J. Electroanal. Chem. 2019, 833, 231.

[103] Ma, Y.; Li, Y.; Li, P.; Li, Q. Int. J. Electrochem. Sci. 2019, 14, 743.

[104] Liu, Z.; Fu, G.; Li, J.; Liu, Z.; Xu, L.; Sun, D.; Tang, Y. Nano Res. 2018, 11, 4686.

[105] Li, F.; Li, W.; Liu, H.; Liu, C.; Dong, G.; Liu, J.; Peng, K. Russ. J. Phys. Chem. A 2018, 92, 1550.

[106] Juárez-Marmolejo, L.; Pérez-Rodríguez, S.; de Oca-Yemha, M. M.; Palomar-Pardavé, M.; Romero-Romo, M.; Ezeta-Mejía, A.; Morales-Gil, P.; Martínez-Huerta, M.; Lázaro, M. Int. J. Hydrog. Energy 2019, 44, 1640.

[107] Jiang, K.; Zhang, J.; Chen, J. J. Solid State Electrochem. 2018, 22, 1941.

[108] Huang, L.; Yang, J.; Wu, M.; Shi, Z.; Lin, Z.; Kang, X.; Chen, S. J. Power Sources 2018, 398, 201.

[109] Ulas, B.; Caglar, A.; Yılmaz, S.; Ecer, U.; Yilmaz, Y.; Sahan, T.; Kivrak, H. Int. J. Energy Res. 43, 8985.

Received September 23, 2019 Accepted November 17, 2019 